\title{
First German Guideline on Diagnostics and Therapy of Clinically Non-Functioning Pituitary Tumors
}

Authors

Timo Deutschbein ${ }^{1,2}$ (D), Cornelia Jaursch-Hancke ${ }^{3}$, Ulrich J. Knappe ${ }^{4}$, Wolfgang Saeger ${ }^{5}$, Jörg Flitsch ${ }^{6}$, Jörg Bojunga7, Michael Buchfelder ${ }^{8}$, Beate Ditzen ${ }^{9}$, Rüdiger Gerlach ${ }^{10}$, Elfriede Gertzen ${ }^{11}$, Jürgen Honegger ${ }^{12}$, Gerhard A.

Horstmann ${ }^{13}$, Arend Koch ${ }^{14}$, Ilonka Kreitschmann-Andermahr ${ }^{15}$ D, Mirjam Kunz ${ }^{16}$, Wolf A. Lagrèze ${ }^{17}$, Nils H. Nicolay ${ }^{18}$, Werner Paulus ${ }^{19}$, Martin Reincke ${ }^{20}$, Manuel A. Schmidt ${ }^{21}$, Matthias M. Weber ${ }^{22}$, Helmut Wilhelm ${ }^{23}$, Martin Fassnacht ${ }^{1}$

\section{Affiliations}

1 Department of Internal Medicine I, Division of Endocrinology and Diabetes, University Hospital Würzburg, University of Würzburg, Würzburg, Germany

2 Medicover Oldenburg MVZ, Oldenburg, Germany

3 Department of Endocrinology, German Clinic of Diagnostics, Wiesbaden, Germany

4 Department of Neurosurgery, Johannes Wesling Hospital, University Hospital of the Ruhr-University Bochum, Minden, Germany

5 Institute for Neuropathology, University Hospital Hamburg-Eppendorf, Hamburg, Germany

6 Department of Neurosurgery, University Medical Center Hamburg-Eppendorf, Hamburg, Germany

7 Department of Internal Medicine I, Division of Endocrinology, Goethe-University Hospital, Frankfurt, Germany

8 Department of Neurosurgery, University Hospital Erlangen, Friedrich-Alexander University of ErlangenNürnberg, Erlangen, Germany

9 Institute of Medical Psychology, Center for Psychosocial Medicine, University Hospital Heidelberg, RuprechtKarls University Heidelberg, Heidelberg, Germany

10 Department of Neurosurgery, Helios Klinikum Erfurt, Erfurt, Germany

11 Niels Stensen Bildungszentrum, Osnabrück, Germany

12 Department of Neurosurgery, University Hospital Tübingen, Eberhard-Karls-University Tübingen, Germany

13 Gamma Knife Center Krefeld, Krefeld, Germany

14 Department of Neuropathology, Berlin Institute of Health, Charité-Universitätsmedizin Berlin, Corporate Member of Freie Universität Berlin, Humboldt-Universität Zu Berlin, Berlin, Germany

15 Department of Neurosurgery and Spine Surgery, University Medicine Essen, University of Duisburg-Essen, Essen, Germany

16 Schwerpunktpraxis für Diabetologie und Endokrinologie, Ludwigshafen, Germany

17 Eye Center, Medical Center, Medical Faculty, University of Freiburg, Germany

18 Department of Radiation Oncology, University of Freiburg - Medical Center, Freiburg, Germany

19 Institute of Neuropathology, University Hospital Münster, Münster, Germany
20 Medizinische Klinik und Poliklinik IV, Klinikum der Universität, Ludwig-Maximilians-Universität München, München, Germany

21 Department of Neuroradiology, University Hospital Erlangen, Friedrich-Alexander-Universität ErlangenNürnberg, Erlangen, Germany

22 Department of Endocrinology and Metabolism, I Medical Clinic, University Hospital, Johannes Gutenberg University of Mainz, Mainz, Germany

23 Centre for Ophthalmology, University Hospital Tübingen, Eberhard-Karls-University Tübingen, Tübingen, Germany

Key words

Adenoma, endocrinology, hormonally inactive, hormones, imaging, neuropathology, neuroradiology, neurosurgery, NFA, pathology, radiology, radiotherapy, recommendation, surgery, sellar mass, treatment.

received 23.01 .2021

received 23.01 .2021

accepted 25.01.2021

Bibliography

Exp Clin Endocrinol Diabetes 2021; 129: 250-264

DOI 10.1055/a-1386-9145

ISSN 0947-7349

(c) 2021. Thieme. All rights reserved.

Georg Thieme Verlag KG, Rüdigerstraße 14,

70469 Stuttgart, Germany

$\oplus$ Supplementary material for this article is available under https://doi.org/10.1055/a-1386-9145.

Correspondence

Priv.-Doz. Dr. med. Timo Deutschbein

University Hospital Würzburg

Department of Internal Medicine I

Division of Endocrinology and Diabetes

Oberdürrbacher Straße 6

97080 Würzburg

Germany

Tel.: +49-(0)931-201-39200, Fax: +49-(0)931-201-639200

deutschbein_t@ukw.de 


\section{ABSTRACT}

Although non-functioning pituitary tumors are frequent, diagnostic and therapeutic concepts are not well standardized. We here present the first German multidisciplinary guideline on this topic. The single most important message is to manage the patients by a multidisciplinary team (consisting at least of an endocrinologist, a neurosurgeon, and a (neuro-) radiologist). The initial diagnostic work-up comprises a detailed characterization of both biochemical (focusing on hormonal excess or deficiency states) and morphological aspects (with magnetic resonance imaging of the sellar region). An ophthalmological examination is only needed in presence of symptoms or large tumors affecting the visual system. Asymptomatic, hormonally inactive tumors allow for a 'wait and scan' strategy. In contrast, surgical treatment by an experienced pituitary surgeon is standard of care in case of (impending) visual impairment. Therapeutic options for incompletely resected or recurrent tumors include re-operation, radiotherapy, and observation; the individual treatment plan should be developed multidisciplinary. Irrespective of the therapeutic approach applied, patients require long-term follow-up. Patient with larger pituitary tumors or former surgery/radiotherapy should be regularly counseled regarding potential symptoms of hormonal deficiency states.

\section{Introduction}

Pituitary tumors are frequent. According to data from autopsy studies, they occur in adults with a prevalence of about $10 \%$. More than $85 \%$ of pituitary tumors are pituitary adenomas, and about $25-30 \%$ of these are hormonally inactive. The latter thus represent the second most frequent tumor type after prolactinomas. They are the focus of this guideline. Hormonally active pituitary adenomas or tumors that do not primarily originate in the pituitary gland are, in this guideline, primarily considered as differential diagnoses. With respect to the therapy of these other tumors, reference is made to other relevant guidelines and recommendations.

Despite the relative frequency of pituitary tumors, the current study situation is limited, at least regarding some clinical questions. The guideline committee agrees that a structured, multidisciplinary approach is essential for optimal patient care. The guideline presented here by 12 medical societies and a patient self-help group aims to provide practical recommendations for the management of patients with hormonally inactive pituitary tumors based on international guidelines and current publications.

The original guideline in German language consists of the following documents:

- Long version with recommendation texts, background information and a detailed report on the methodology (guideline report).

- Short version with the most important recommendations and tables in short form.

- Summary of the guideline as targeted information for patients.

All three documents are freely available at http://awmf-leitlinien. de. Here, we present a short version of this guideline in English. An English translation of the entire guideline report is available in the Appendix. After a short review of the methodology, all recommendations will be presented in boxes along with a short explanatory text. For more details and references, we refer to the full version.

\section{Methodology}

At the first meeting of the guideline committee on June $19^{\text {th }} 2018$, the main clinical questions to be addressed by the guideline were defined. Based on the existing international guidelines [1-13] and extensive primary literature, recommendations and background texts were subsequently developed by seven working groups. According to the guidelines of the Association of the Scientific Medical Societies in Germany (Arbeitsgemeinschaft der Wissenschaftlichen Medizinischen Fachgesellschaften e.V., AWMF), the recommendations were graded using the wording "shall" (strong recommendation), "should" (recommendation), and "can" (open recommendation).

All recommendations as well as some of the contents of the explanatory text were discussed at the second meeting of the guideline committee on February 19th 2019, and at the consensus conference on June $25^{\text {th }} 2019$, before being finally approved. The course of the consensus conference was structured in the sense of a nominal group process. All recommendations were approved by consensus or strong consensus. The strength of consensus was defined as follows (respective approval rate given in brackets): strong consensus (>95\%), consensus ( > 75-95\%), majority consensus (50-75\%), no consensus ( $<50 \%$ ).

Following the consensus conference, the comments were first modified by the various working group leaders, taking into account the decisions made, before a final editorial revision of the entire guideline by the secretary and the two coordinators was performed. The guideline was then submitted to all participating professional societies for comments on November $6^{\text {th }} 2019$, and finally approved by them by December $20^{\text {th }} 2019$. The AWMF then carried out an external formal assessment. The last revision of the content of this guideline took place in December 2019. The guideline was published in January 2020 and will be valid for 5 years (i. e., until December 2024).

\section{Definition and General Recommendation}

Pituitary tumors are common in adults and, with rare exceptions, benign (see details in $>$ Table 1 ). More than $85 \%$ of all tumors in the sellar region are pituitary adenomas. A fraction of the latter is hormonally active, and these tumors are not addressed in detail in this guideline. It is common clinical practice to designate pituitary tumors with a size of $<1 \mathrm{~cm}$ as microtumors (or microadenomas) and, accordingly, tumors with a size of $\geq 1 \mathrm{~cm}$ as macrotumors (or macroadenomas); although this cutoff is, of course, arbitrary. 
$\checkmark$ Table 1 Differential diagnoses of tumors in the sellar region.

\begin{tabular}{|c|c|}
\hline Tumor entity & $\begin{array}{l}\text { Relative } \\
\text { frequency }\end{array}$ \\
\hline Formally benign tumors & $91.4 \%$ \\
\hline $\begin{array}{l}\text { Pituitary adenomas } \\
\text { - Hormonally inactive adenomas } \\
\text { - Prolactin-producing adenomas (prolactinomas) } \\
\text { - GH-producing adenomas (acromegaly) } \\
\text { - ACTH-producing adenomas (Cushing's disease) } \\
\text { - TSH-producing adenomas (TSH-omas) } \\
\text { - Gonadotropin-producing adenomas (gonadotropinomas) }\end{array}$ & $86.6 \%$ \\
\hline Craniopharyngiomas & $3.1 \%$ \\
\hline Meningiomas & $1.3 \%$ \\
\hline $\begin{array}{l}\text { Posterior pituitary tumors (e.g. spindle cell oncocytoma, } \\
\text { pituicytoma, granular cell tumor) }\end{array}$ & $0.4 \%$ \\
\hline Cysts & $4.5 \%$ \\
\hline Rathke’s cleft cysts & $3.6 \%$ \\
\hline Colloid cysts & $0.6 \%$ \\
\hline Arachnoid cysts & $0.2 \%$ \\
\hline Dermoid cysts & $0.2 \%$ \\
\hline Pituitary hyperplasia & $0.2 \%$ \\
\hline Lactotroph hyperplasia (during pregnancy) & $0.1 \%$ \\
\hline Thyrotroph and gonadotroph hyperplasia & $<0.1 \%$ \\
\hline Other entities (selection) & $2.3 \%$ \\
\hline Pituitary abscess & $0.3 \%$ \\
\hline Lymphocytic hypophysitis & $0.3 \%$ \\
\hline Malignant tumors & $1.6 \%$ \\
\hline $\begin{array}{l}\text { Metastases of other malignomas (e. g., lung or breast } \\
\text { carcinomas) }\end{array}$ & $0.7 \%$ \\
\hline Chordomas & $0.4 \%$ \\
\hline Pituitary carcinomas & $0.2 \%$ \\
\hline Germ cell tumors (germinomas) & $0.2 \%$ \\
\hline Chondrosarcomas & $0.1 \%$ \\
\hline \multicolumn{2}{|c|}{$\begin{array}{l}\text { The data on relative frequencies were taken from the German Pituitary } \\
\text { Registry containing more than } 11,000 \text { operated tumors. By definition, } \\
\text { only operated cases are included in this registry. Therefore, prolactino- } \\
\text { mas, (small) benign hormonally inactive masses (which are often not } \\
\text { operated on), and tumors that are frequently transcranially resected are } \\
\text { obviously underrepresented in this registry. Abbreviations: ACTH, } \\
\text { adrenocorticotropic hormone; GH, growth hormone; TSH, thyroid- } \\
\text { stimulating hormone. }\end{array}$} \\
\hline
\end{tabular}

\begin{tabular}{|l|l|l|}
\hline No. & Recommendation & Consensus \\
\hline 3.1 & Every patient with a newly detected or & Strong \\
& known pituitary tumor shall be diagnosed & \\
& and treated by a multidisciplinary team of & \\
& physicians* experienced in the treatment of & \\
& pituitary tumors. & \\
& * Mandatory disciplines in this team are & \\
& endocrinology, neurosurgery, and (neuro-) & \\
& radiology, as well as, depending on the & \\
& tumor size or the planned intervention, & \\
& (neuro-) pathology, ophthalmology, and & \\
& radiotherapy. In case of special issues, other & \\
& disciplines (e. g., gynecology, neurology, and & \\
& psychology), may also be required. & \\
\hline
\end{tabular}

\section{Short explanation}

To ensure adequate diagnostics, therapy, and follow-up, patients with pituitary tumors require special expertise that usually will only be provided through multidisciplinary care.

\section{Diagnostics}

\begin{tabular}{|l|l|l|}
\hline No. & Recommendations & Consensus \\
\hline 4.1 & $\begin{array}{l}\text { In patients with a pituitary tumor, a detailed } \\
\text { medical history and clinical examination shall be } \\
\text { performed in order to evaluate possible } \\
\text { symptoms of pituitary insufficiency or hormone } \\
\text { excess as well as local symptoms caused by the } \\
\text { tumor mass. }\end{array}$ & Strong \\
\hline 4.2 & $\begin{array}{l}\text { In patients with clinically non-functioning } \\
\text { pituitary tumors, biochemical confirmation of } \\
\text { endocrine inactivity shall be performed. } \\
\text { Possible hormone activity shall be clarified } \\
\text { through basal morning measurement of } \\
\text { prolactin, thyroid-stimulating hormone (TSH), } \\
\text { free thyroxine (fT4), free triiodothyronine (fT3), } \\
\text { luteinizing hormone (LH), follicle-stimulating } \\
\text { hormone (FSH), total testosterone (in men) or } \\
\text { estradiol (in premenopausal women), insulin-like } \\
\text { growth factor 1 (IGF-1), and a 1 mg dexametha- } \\
\text { sone suppression test. }\end{array}$ & \\
\hline 4.3 & $\begin{array}{l}\text { In macroadenomas, pituitary insufficiency shall } \\
\text { be ruled out. This includes basal morning } \\
\text { measurement of TSH, fT4, fT3, LH, FSH, total } \\
\text { testosterone (in men) or estradiol (in premenopau- } \\
\text { sal women), cortisol, and IGF-1. } \\
\text { In case of abnormalities further dynamic testing } \\
\text { procedures shall be carried out. } \\
\text { Larger microadenomas (with a size of 6-9mm) } \\
\text { may also lead to pituitary insufficiency and should, } \\
\text { therefore, be biochemically evaluated accordingly. }\end{array}$ & \\
\hline
\end{tabular}

\section{Short explanation}

A detailed diagnostic work-up (including medical history, clinical examination, and endocrine analysis) is the mainstay of an adequate patient management. In $85 \%$ of hormonally inactive macroadenomas, clinical evidence of pituitary insufficiency is already present at initial diagnosis $[5,14]$. For anamnestic clues, specific symptoms, and detailed explanation for the selection of the recommended hormones, we refer to the Appendix. \ Table 2 summarizes the hormone parameters that are regarded as mandatory for the initial evaluation of patients with pituitary tumors.

Assessment of corticotropic function includes determination of basal morning serum cortisol as the first step:

- Basal serum cortisol $\leq 4.0 \mu \mathrm{g} / \mathrm{dL}(110 \mathrm{nmol} / \mathrm{L})$ : high probability of secondary adrenal cortical insufficiency.

- Basal serum cortisol $\geq 15.0 \mu \mathrm{g} / \mathrm{dL}(414 \mathrm{nmol} / \mathrm{L})$ : high probability of corticotropic axis sufficiency.

- If a basal serum cortisol in the diagnostic gray range is detected (i.e., $4.1-14.9 \mu \mathrm{g} / \mathrm{dL}(111-413 \mathrm{nmol} / \mathrm{L})$ ), a dynamic functional test needs to be performed (gold standard: insulin hypoglycemia test; alternatively: metopyrone test, adrenocorticotropic hormone (ACTH) test (using $250 \mu \mathrm{g}$ Synacthen $\left.{ }^{\circledR}\right)$, or corticotropin-releasing hormone (CRH) test). 


\begin{tabular}{|l|l|l|}
\hline No. & Recommendations & Consensus \\
\hline 4.4 & $\begin{array}{l}\text { Magnetic resonance imaging of the sellar region } \\
\text { shall be performed for the radiological detection } \\
\text { and characterization of pituitary tumors. }\end{array}$ & Strong \\
\hline 4.5 & $\begin{array}{l}\text { For pituitary tumors that are in contact with the } \\
\text { visual path according to magnetic resonance } \\
\text { imaging, ophthalmologic evaluation shall be } \\
\text { performed. }\end{array}$ & Strong \\
\hline
\end{tabular}

\section{Short explanation}

Due to superior space resolution in the sellar and supresellar region, magnetic resonance imaging (MRI) is - in comparison to computed tomography (CT) - clearly the gold standard in the diagnosis of pituitary adenomas. A possible protocol for MRI imaging of the sellar region (including information on dynamic contrast agent sequences) is presented in $>$ Table 3.

- Table 2 Mandatory hormone parameters at initial diagnosis of a pituitary tumor.

\begin{tabular}{|l|}
\hline Laboratory parameters \\
\hline - Prolactin \\
\hline - TSH, fT4, fT3 \\
\hline - LH, FSH, sex hormones \\
- Estrogen in premenopausal women \\
- Total testosterone in men \\
\hline - IGF-1 \\
\hline - Basal morning cortisolA \\
\hline - 1 mg dexamethasone suppression test \\
\hline $\begin{array}{l}\text { A Cortisol is usually only to be determined for macroadenomas and large } \\
\text { microadenomas ( } \geq 6 \text { mm); borderline findings require dynamic function }\end{array}$ \\
tests (see text below). Abbreviations: FSH, follicle-stimulating hormone; \\
fT3, free triiodothyronine; fT4, free thyroxine; IGF-1, insulin-like growth \\
factor 1; LH, luteinizing hormone; TSH, thyroid-stimulating hormone. \\
\hline
\end{tabular}

- Table 3 Recommendation for a MRI imaging protocol of the sellar region.

\begin{tabular}{|c|c|}
\hline & Description \\
\hline \multirow{5}{*}{$\begin{array}{l}\text { MRI } \\
\text { characteristics }\end{array}$} & $\begin{array}{l}\text { A field strength of at least } 1.5 \text { and ideally } 3 \text { Tesla, a slice } \\
\text { thickness of } 1.5-2 \mathrm{~mm} \text {, a small field of view, a high matrix } \\
\text { and, ideally, an in-plane resolution of } 0.5 \mathrm{~mm} \times 0.5 \mathrm{~mm}\end{array}$ \\
\hline & $\begin{array}{l}\text { T2 weighting (T2w) in the coronal plane, aligned with the } \\
\text { infundibulum (sagittal T2w localizer); in addition, at least } \\
\text { one slice in the axial or sagittal plane }\end{array}$ \\
\hline & T1 weighting (T1w) coronal and sagittal native \\
\hline & $\begin{array}{l}\text { T1w coronal and sagittal after intravenous administration } \\
\text { of contrast medium (e. g., } 0.05 \mathrm{mmol} / \mathrm{kg} \text { body weight (for } \\
\text { microadenomas) or } 0.1 \mathrm{mmol} / \mathrm{kg} \text { body weight (for } \\
\text { macroadenomas) of a gadolinium-containing contrast } \\
\text { medium) }\end{array}$ \\
\hline & $\begin{array}{l}\text { 3D T1 MPRAGE volume data set with an isotropic voxel } \\
\text { size of } 1 \mathrm{~mm} \text { after intravenous administration of contrast } \\
\text { medium }\end{array}$ \\
\hline \multirow{7}{*}{$\begin{array}{l}\text { Administration } \\
\text { of contrast } \\
\text { medium }\end{array}$} & Contrast medium flow rate: $2 \mathrm{ml} / \mathrm{s}$ \\
\hline & Time of injection: start of $2^{\text {nd }}$ dynamic measurement \\
\hline & Duration of the dynamic measurement: $30 \mathrm{~s}$ max. \\
\hline & Number of measurements: 6-8 \\
\hline & MRI sequence: coronal T1 turbo spin echo \\
\hline & Voxel size: $0.5 \times 0.5 \times 2 \mathrm{~mm}$ \\
\hline & Flushing: $20 \mathrm{ml} \mathrm{NaCl}$ flush with a flow rate of $2 \mathrm{ml} / \mathrm{s}$ \\
\hline
\end{tabular}

Visual disturbances including visual field defects and blindness may be observed in more than half of pituitary macroadenomas. As the defects develop slowly and are partly compensated by the unaffected eye, they are not necessarily noticed by the patients. The ophthalmologic evaluation includes the measurement of visual acuity and visual field as well as an examination of the fundus. As a rule, static perimetry of the central 30 degrees of the visual field is sufficient.

\section{Therapy}

\section{Procedures for initial diagnosis}

\begin{tabular}{|c|c|c|}
\hline No. & Recommendations & Consensus \\
\hline 5.1 & $\begin{array}{l}\text { In case of asymptomatic, hormonally inactive } \\
\text { pituitary microtumors ( }<1 \mathrm{~cm}) \text {, the patient shall } \\
\text { primarily be monitored ("wait and scan"). } \\
\text { In most asymptomatic, hormonally inactive } \\
\text { pituitary macrotumors ( } \geq 1 \mathrm{~cm} \text { ), the patient can } \\
\text { primarily be monitored ("wait and scan"). }\end{array}$ & Strong \\
\hline 5.2 & $\begin{array}{l}\text { In case of symptomless, hormonally inactive } \\
\text { pituitary tumors, as a rule, drug therapy with } \\
\text { dopamine agonists should not be performed. } \\
\text { If it is unclear whether, in a clinically hormone- } \\
\text { inactive adenoma, functional hyperprolactinemia or } \\
\text { rather a prolactinoma is present, temporary } \\
\text { treatment with dopamine agonists can be } \\
\text { attempted. } \\
\text { Follow-up should be both via determination of } \\
\text { serum prolactin levels and radiologically. }\end{array}$ & Strong \\
\hline 5.3 & $\begin{array}{l}\text { In case of an (impending) impairment of vision, } \\
\text { surgical treatment of the pituitary tumor shall be } \\
\text { performed. } \\
\text { Tumors showing significant growth in size } \\
\text { (particularly with regard to critical surrounding } \\
\text { structures such as the visual pathway) should be } \\
\text { operated on. } \\
\text { The detection of a relevant pituitary insufficiency } \\
\text { can be considered an indication for surgery. } \\
\text { Pituitary tumors are rarely the cause of headache, } \\
\text { therefore, an indication for surgery based on this } \\
\text { symptom alone should be made with caution. }\end{array}$ & Strong \\
\hline 5.4 & $\begin{array}{l}\text { In case of severe or rapidly progressive neuro- } \\
\text { ophthalmologic deficits, an emergency presenta- } \\
\text { tion to a neurosurgeon shall be performed. }\end{array}$ & Strong \\
\hline 5.5 & $\begin{array}{l}\text { Neurosurgical intervention should be performed by } \\
\text { a neurosurgeon with sufficient experience in } \\
\text { pituitary surgery. }\end{array}$ & Strong \\
\hline 5.6 & $\begin{array}{l}\text { Since the results of microsurgical and endoscopic } \\
\text { transsphenoidal surgery are equivalent, the choice } \\
\text { of the visualization mode should depend on the } \\
\text { surgeon's experience with the optical technique and } \\
\text { his preference. }\end{array}$ & Strong \\
\hline 5.7 & $\begin{array}{l}\text { When using a transsphenoidal access, the sphenoid } \\
\text { sinus and the sella turcica shall be opened wide } \\
\text { enough to remove all tumor parts that were } \\
\text { considered resectable preoperatively. }\end{array}$ & Strong \\
\hline 5.8 & $\begin{array}{l}\text { Neuronavigation and intraoperative ultrasound } \\
\text { imaging can be used to increase the safety and the } \\
\text { resection rate in transsphenoidal surgery of } \\
\text { pituitary tumors. } \\
\text { Intraoperative magnetic resonance imaging can be } \\
\text { used to increase the resection rate in pituitary } \\
\text { tumor surgery. }\end{array}$ & Strong \\
\hline
\end{tabular}




\section{Short explanation}

As published data and our experience indicate that a relevant increase in size or new endocrine dysfunction are rare events, a "wait and scan" strategy is actually the preferred option for patients with incidentally detected asymptomatic pituitary microadenomas. The advantages and disadvantages of this procedure as compared to surgery need to be discussed with the patient in detail.

Due to the moderate number of published series and, thus, comparatively small numbers of reported cases, the evidence for a recommendation regarding the therapy of asymptomatic hormone-inactive pituitary adenomas with dopamine agonists is insufficient. However, the differentiation of hormone-inactive pituitary adenomas from prolactinomas in the presence of mild to moderate hyperprolactinemia may be difficult in individual cases. Thus, in these unclear cases, treatment with dopamine agonists seems justified.

The indications for the operation of pituitary tumors result from the different (impending) complications of these tumors, and the guideline committee deliberately formulates specific strength of recommendation for each indication. Usually, transsphenoidal surgery is the appropriate first-line therapy for symptomatic hormoneinactive pituitary adenomas. Transcranial surgery is rarely indicated as a primary intervention. The previous experience of a pituitary surgeon and the annual number of cases of transsphenoidal surgeries performed influence the resection result and the complication rate. Studies on radiotherapy as a primary treatment have not been able to demonstrate results comparable to those of surgical procedures [10].

The chiasmal syndrome is an absolute indication for surgery. If the visual impairment has not yet set in, but is imminent, the guideline committee also sees a clear indication for surgery. The members of the guideline committee are convinced, though, that the sudden onset of symptoms in the context of a pituitary apoplexy requires high attention.

During initial observation of a clinically non-functioning pituitary adenoma, surgery is indicated if in the course of time a significant progression in size is observed. Size progression is difficult to define. In the full version in the Appendix approaches to this problem are discussed.

In the presence of anterior pituitary insufficiency, the guideline committee also makes a recommendation for transsphenoidal surgery (at least if $\geq 2$ pituitary axes are affected). However, this is deliberately formulated as a "can-recommendation".

Data on the causal relationship between headache and pituitary tumors are inconclusive. Nevertheless, the authors of the guideline are convinced that headache alone is a rare indication for surgery.

The complication rates in large series did not exhibit a significant difference between microsurgically and endoscopically operated patients and therefore, the method applied depends on the surgeon's preference.

At first glance, intraoperative MRI seems to have a positive influence on the surgical results. However, the method is time-consuming and cost-intensive. In addition, either the use of special non-magnetic instruments or repositioning of the anesthetized patient is required for the examination. Despite positive effects on safety (neuronavigation) and resection rate (intraoperative imaging), in the opinion of the neurosurgeons involved in the develop- ment of this guideline, neither image-guided surgery nor intraoperative imaging are able to replace the experience of the surgeon as the decisive factor for the success of the operation.

\section{Perioperative management}

\begin{tabular}{|c|c|c|}
\hline No. & Recommendations & Consensus \\
\hline 5.9 & $\begin{array}{l}\text { If secondary adrenal insufficiency is present or } \\
\text { suspected, adequate glucocorticoid substitution } \\
\text { shall be performed. } \\
\text { The perioperative substitution of hydrocorti- } \\
\text { sone in the resection of pituitary tumors should } \\
\text { be performed according to a standardized local } \\
\text { protocol. }\end{array}$ & Strong \\
\hline 5.10 & $\begin{array}{l}\text { In case of possible or proven postoperative } \\
\text { adrenal insufficiency, patients shall be adequately } \\
\text { informed before discharge from hospital about } \\
\text { the required medication and the necessity of a } \\
\text { need-based adaptation (see also Recommenda- } \\
\text { tion } \mathbf{8 . 1} \text { and Recommendation } \mathbf{8 . 2} \text { ). }\end{array}$ & Strong \\
\hline 5.11 & $\begin{array}{l}\text { In case of pre- or postoperative evidence of } \\
\text { hypothyroidism, corticotropic insufficiency shall } \\
\text { be excluded before starting a substitution thera- } \\
\text { py; otherwise, it may clinically unmask. } \\
\text { For diagnosis as well as dose titration of the } \\
\text { thyroid hormone substitution therapy, fT4 (and } \\
\text { not the, in this case, frequently suppressed or } \\
\text { inadequately low TSH) shall be taken into } \\
\text { account. }\end{array}$ & Strong \\
\hline 5.12 & $\begin{array}{l}\text { In order to detect a possible syndrome of } \\
\text { inadequate antidiuretic hormone (ADH) } \\
\text { secretion (SIADH) and/or diabetes insipidus } \\
\text { early, serum electrolytes shall be determined } \\
\text { regularly after surgery until at least the } 10^{\text {th }} \\
\text { postoperative day, and patients shall be } \\
\text { informed in appropriate detail. }\end{array}$ & Strong \\
\hline 5.13 & $\begin{array}{l}\text { After a neurosurgical intervention, the possible } \\
\text { occurrence of cerebrospinal fluid fistulas, } \\
\text { meningitis, and visual disturbances shall be paid } \\
\text { attention to. }\end{array}$ & Strong \\
\hline 5.14 & $\begin{array}{l}\text { Short-term postoperative imaging of the sellar } \\
\text { region is usually unnecessary and should be } \\
\text { reserved for certain questions (e.g., to assess } \\
\text { the size of intraoperative tumor remnants, } \\
\text { newly occurring visual disturbances or } \\
\text { neurological deficits with regard to postopera- } \\
\text { tive bleeding or vascular injury). } \\
\text { The first regular imaging control should be } \\
\text { performed 3-6 months after surgery. }\end{array}$ & Strong \\
\hline
\end{tabular}

\section{Short explanation}

A variety of perioperative substitution regimens has been described in the literature, differing in glucocorticoid dose and duration of administration. Common substitution regimens for the immediate perioperative phase are $50 \mathrm{mg}$ or $100 \mathrm{mg}$ hydrocortisone intraoperatively and $50 \mathrm{mg}$ or $100 \mathrm{mg}$ hydrocortisone over 24 hours by perfusion. Thereafter, the dose is gradually decreased until a maintenance dose is reached.

On discharge from hospital, a daily hydrocortisone dose of $15-30 \mathrm{mg}$ is usual (about 2/3 in the morning and 1/3 at noon; alternatively, division into 3 daily doses is possible). This maintenance 
dose then has to be kept unchanged until postoperative endocrine re-evaluation (i. e., 6-12 weeks after surgery) and has to be adapted in situations of increased need.

Postoperative electrolyte alterations due to a disorder of antidiuretic hormone $(A D H)$ release by the posterior pituitary lobe are frequently observed. They are of central importance for the early postoperative management of patients after pituitary surgery. Diabetes insipidus centralis due to a lack of ADH usually occurs in the first postoperative days. The syndrome of inadequate $A D H$ release (SIADH) as the opposite disorder usually occurs with a delay of several days after surgery. Accordingly, close supervision of electrolytes is reasonable at least until the $10^{\text {th }}$ postoperative day. More details on the management of postoperative diabetes insipidus centralis or SIADH are given in the full version of this guideline in the Appendix.

An MRI examination provides more reliable results if it is not performed immediately, but rather not earlier than 3-6 months after the operation. One of the reasons is that, after this period of time, an assessment of the size of residual tumor tissue is less complicated by post-operative changes and artifacts [16].

\section{Recommendations for residual and recurrent tumors}

\begin{tabular}{|l|l|l|}
\hline No. & Recommendations & Consensus \\
\hline 5.15 & $\begin{array}{l}\text { In case of residual or recurrent tissue of a } \\
\text { hormone-inactive pituitary tumor, observation } \\
\text { ("wait and scan"), re-operation, and radiothera- } \\
\text { py shall be considered (if possible, in a } \\
\text { multidisciplinary case conference with } \\
\text { endocrinological, neurosurgical, (neuro-) } \\
\text { pathological, (neuro-) radiological, ophthal- } \\
\text { mological, and radiotherapeutic participation). }\end{array}$ & Strong \\
\hline 5.16 & $\begin{array}{l}\text { The radiotherapy of residual/recurrent tissue } \\
\text { of hormone-inactive pituitary adenomas can } \\
\text { be performed by radiosurgery depending on } \\
\text { the individual patho-anatomical conditions. }\end{array}$ & Strong \\
\hline 5.17 & $\begin{array}{l}\text { Radiotherapy of residual/recurrent tissue of } \\
\text { hormone-inactive pituitary adenomas can be } \\
\text { performed by fractionated radiotherapy. } \\
\text { Radiation therapy of pituitary adenomas that } \\
\text { are not eligible for radiosurgery (e. g., in the } \\
\text { vicinity of the optical system) should be } \\
\text { fractionated. }\end{array}$ & Strong \\
\hline 5.19 & $\begin{array}{l}\text { In case of postoperative tumor growth and } \\
\text { after exhaustion of surgical and radiotherapeu- } \\
\text { tic options, treatment of hormone-inactive } \\
\text { pituitary adenomas with dopamine agonists } \\
\text { can be considered in individual cases. For } \\
\text { somatostatin analogues, evidence is } \\
\text { insufficient in this indication. }\end{array}$ & Strong \\
\hline $\begin{array}{l}\text { As first-line chemotherapy for aggressive } \\
\text { pituitary adenomas with documented tumor } \\
\text { growth and lack of surgical or radiotherapeutic } \\
\text { treatment options, monotherapy with } \\
\text { temozolomide should be performed. }\end{array}$ & Strong \\
\hline 5.18 & \\
\hline
\end{tabular}

\section{Short explanation}

The most reasonable step for recurrent adenomas is a multidisciplinary discussion of the case and an individualized decision.

In large recurrent adenomas with an invasive component, the concept of surgical tumor debulking with subsequent radiotherapy may also be pursued. In the case of progressive residual findings of hormone-inactive pituitary adenomas, radiotherapy achieves high control rates of about $90 \%$ after 10 years.

Radiosurgery is a highly conformal, single-session radiotherapy with steep dose gradients. In hormone-inactive pituitary tumors, single doses of 12Gy or more are effective, and edge doses of up to 16Gy have been described in clinical cohorts.

The decision between single-session radiosurgery and hypofractionated radiosurgery is - also in consideration of conventional fractionated radiotherapy - based on the anatomical situation, especially the proximity to the optical system and the size of the target volume. For tumors that do not fall below a minimum distance from the optical system (optic nerve and optic chiasm) of $2 \mathrm{~mm}$, single-stage radiosurgery is more appropriate. In case of contact (without compression) or a distance of less than $2 \mathrm{~mm}$, hypofractionated radiosurgery may be performed [17].

Tumors that are not delimitable (i. e., they are diffusely infiltrating), walling around the optical system or symptomatic tumor masses constitute contraindications for radiosurgery.

Although there are no comparative studies that have investigated the response rates of fractionated radiotherapy vs. radiosurgery, numerous retrospective cohort analyses show approximately comparable control rates of both procedures in hormone-inactive pituitary adenomas. In the case of large tumors that are no longer accessible to stereotactic radiosurgery or in cases of critical proximity to the optical structures, especially the optic chiasm, fractionated radiotherapy is the method of choice to avoid the effects of high single doses to the optical system.

Usually, fractionated radiotherapy uses doses between 45Gy and 54Gy in 5 fractions of 1.8Gy to 2Gy per week over a period of 5 to 6 weeks.

Due to the limited number of subjects and the lack of further randomized studies on the use of drug therapy of hormone-inactive adenomas, the authors of the guideline do not consider the data situation robust enough to make a general recommendation. However, in case of so-called aggressive adenomas the situation is slightly different. These tumors are characterized by radiologically invasive growth and an unusually rapid growth rate, or they show a clinically relevant growth despite optimal standard therapies. In these rare tumors, temozolomide is treatment of choice following a recent recommendation of the European Society of Endocrinology [13]. 


\section{Pathology}

\begin{tabular}{|c|c|c|}
\hline No. & Content & Consensus \\
\hline 6.1 & $\begin{array}{l}\text { Surgically resected tissue from a pituitary } \\
\text { tumor shall be processed and evaluated } \\
\text { according to the criteria of the the currentlx } \\
\text { valid World Health Organization (WHO) } \\
\text { classification for tumors of endocrine organs } \\
\text { and tumors of the central nervous system. }\end{array}$ & Strong \\
\hline 6.2 & $\begin{array}{l}\text { For the histopathological work-up of pituitary } \\
\text { adenomas, antibodies against the pituitary } \\
\text { hormones (growth hormone (GH), prolactin, } \\
\text { TSH, ACTH, FSH, LH, alpha-subunit), the } \\
\text { three pituitary transcription factors } \\
\text { (pituitary-specific positive transcription } \\
\text { factor } 1 \text { (PIT-1), T-box factor pituitary (T-PIT), } \\
\text { steroidogenic factor } 1 \text { (SF-1)), the estrogen } \\
\text { receptor, and the proliferation marker Ki-67 } \\
\text { shall be held available in the laboratory } \\
\text { according to the WHO classification. }\end{array}$ & Strong \\
\hline 6.3 & $\begin{array}{l}\text { Since the identification of certain hormone- } \\
\text { producing as well as transcription factor- } \\
\text { positive pituitary adenomas is of prognostic } \\
\text { relevance, the hormone and transcription } \\
\text { factor subtypes shall be mentioned in the } \\
\text { written pathology report. }\end{array}$ & Strong \\
\hline 6.4 & $\begin{array}{l}\text { For hormone-negative, transcription } \\
\text { factor-positive adenomas, the following } \\
\text { diagnoses shall be applied according to the } \\
\text { WHO classification: } \\
\text { - Hormone-inactive PIT-1 positive pituitary } \\
\text { adenoma (a more precise classification as } \\
\text { GH-prolactin or TSH adenoma is not reliably } \\
\text { possible) } \\
\text { - Hormone-inactive gonadotroph pituitary } \\
\text { adenoma (SF-1 positive adenoma) } \\
\text { - Hormone-inactive corticotroph pituitary } \\
\text { adenoma (T-PIT positive adenoma) }\end{array}$ & Strong \\
\hline 6.5 & $\begin{array}{l}\text { In addition to the histological classification of } \\
\text { a pituitary tumor, its clinical significance and } \\
\text { aggressiveness shall be assessed according to } \\
\text { the WHO classification. This requires clinical } \\
\text { information on the endocrine activity of the } \\
\text { tumor and radiological findings regarding } \\
\text { spread and invasiveness. }\end{array}$ & Strong \\
\hline 6.6 & $\begin{array}{l}\text { If aggressiveness criteria are present, } \\
\text { according to the WHO classification, the } \\
\text { addition "with characteristics of aggressive- } \\
\text { ness" shall be included in the written } \\
\text { pathology report (after the hormone and } \\
\text { transcription factor subtype). }\end{array}$ & Strong \\
\hline 6.7 & $\begin{array}{l}\text { Immunohistology with detection of } \\
\text { somatostatin and dopamine receptors can be } \\
\text { helpful for planning the pharmacotherapy. } \\
\text { If a therapy with temozolomide is considered } \\
\text { for aggressive pituitary adenomas and } \\
\text { carcinomas, O-6-methylguanine-DNA-meth- } \\
\text { yltransferase (MGMT) determination can be } \\
\text { included. }\end{array}$ & Strong \\
\hline 6.8 & $\begin{array}{l}\text { Currently, a molecular genetic examination of } \\
\text { hormone-inactive pituitary adenoma tissue } \\
\text { cannot be recommended due to a lack of } \\
\text { clinical consistency. }\end{array}$ & Strong \\
\hline
\end{tabular}

\section{Short explanation}

In this regard, the currently valid World Health Organization (WHO) classification for endocrine tumors and tumors of the central nervous system $[18,19]$ has become established worldwide in recent years and, thus, represents the basis for neuropathological workup. In the diagnosis of pituitary tumors, a good flow of information between the treating medical disciplines (including neurosurgery, endocrinology), and (neuro-) pathology is essential for the consistent application of the classification recommended by the WHO. Essential information for the (neuro-) pathologist, especially for the assessment of the aggressiveness of a pituitary adenoma, are tumor size, tumor extent or invasiveness in the preoperative MRI, and details on clinical presentation.

The group of clinically non-functioning pituitary tumors includes the "silent" adenomas that do not lead to clinically measurable hormone hypersecretion despite immunohistochemically detectable hormone production, the hormone-negative, transcription factor-positive adenomas, and the hormone- and transcription factor-negative null-cell adenomas.

The determination of the pituitary adenoma subtype is based on structural and immunohistological differences as shown in $\checkmark$ Table 4.

The hormone-negative, but transcription factor-positive adenomas, are either endocrine-inactive/"silent" or endocrine-active and then, if detected, represent the critical correlate for the explanation of pituitary hyperfunction. Thus, PIT-1-positive adenomas are able to explain $\mathrm{GH}$-, prolactin- or TSH-hyperfunction without detection of the expected hormone. Likewise, T-PIT-positive, ACTHnegative adenomas account for $\mathrm{ACTH}$-hyperfunction (in the sense of Cushing's disease or Nelson's syndrome). Finally, SF-1-positive, $\mathrm{FSH}-$, and $\mathrm{LH}$-negative adenomas represent gonadotroph adenomas.

The aggressive adenomas of the new nomenclature of 2017 $[13,19]$ are characterized by a faster growth and a higher recurrence rate. Therefore, the clinician has to provide the pathologist clinically relevant information.

If somatostatin analogues, dopamine agonists or temozolomide are clinically eligible for the treatment of aggressive hormone-inactive adenomas, immunohistochemical staining with antibodies against the somatostatin receptors (SSTR) SSTR2a and SSTR5, the dopamine receptors as well as the determination of 0-6-methylguanine-DNA-methyltransferase (MGMT) expression have proven to be helpful. Although sporadic mutations have been described in up to $60 \%$ of corticotropic adenomas (mainly USP8 and USP48 mutations) and in about $40 \%$ of somatotroph adenomas (mainly GNAS mutations) [20,21], there are no pathogenetically relevant mutations to be frequently found in hormonally inactive adenomas. In principle, molecular pathological detection of mutations has no therapeutic consequences at present and is therefore only carried out within the framework of research projects. 
- Table 4 WHO classification of pituitary adenomas of 2017.

\begin{tabular}{|c|c|c|c|c|c|}
\hline \multirow[b]{2}{*}{ Tumor type } & \multicolumn{2}{|c|}{ Immunohistochemistry } & \multirow[t]{2}{*}{ Aggressive } & \multirow[t]{2}{*}{ Main function } & \multirow[t]{2}{*}{ Possible function } \\
\hline & Hormones and receptors & $\begin{array}{l}\text { Transcription } \\
\text { factor }\end{array}$ & & & \\
\hline \multicolumn{6}{|l|}{ Somatotroph adenomas } \\
\hline Densely granulated GH adenoma & $\begin{array}{l}\text { GH, possibly PRL, a-SU, ER } \\
\text { negative }\end{array}$ & PIT-1 & & Acromegaly & \\
\hline Sparsely granulated GH adenoma & $\begin{array}{l}\mathrm{GH} \text {, possibly PRL, a-SU, ER } \\
\text { negative }\end{array}$ & PIT-1 & Yes & Acromegaly & Silent \\
\hline Undifferentiated GH adenoma & $\begin{array}{l}\mathrm{GH} \text {, possibly PRL, ER } \\
\text { negative }\end{array}$ & PIT-1 & Yes & Acromegaly & Silent \\
\hline \multicolumn{6}{|l|}{ Lactotroph adenomas } \\
\hline Densely granulated PRL adenoma & PRL, ER positive & PIT-1 & & Hyperprolactinemia & \\
\hline Sparsely granulated PRL adenoma & PRL, ER positive & PIT-1 & $\begin{array}{l}\text { Macroadeno- } \\
\text { mas in men }\end{array}$ & Hyperprolactinemia & Silent \\
\hline Acidophil stem cell adenoma & PRL, (GH), ER positive & PIT-1 & Yes & Hyperprolactinemia & Acromegaly \\
\hline Undifferentiated PRL adenoma & PRL, ER positive & PIT-1 & Yes & Hyperprolactinemia & Silent \\
\hline \multicolumn{6}{|l|}{ Mixed GH-Prolactin adenomas } \\
\hline Densely granulated GH/PRL adenoma & GH, PRL, ER positive & PIT-1 & & Acromegaly & Hyperprolactinemia \\
\hline Sparsely granulated GH/PRL adenoma & GH, PRL, ER positive & PIT-1 & & Acromegaly & Hyperprolactinemia \\
\hline Mammosomatotroph adenoma & GH, PRL, ER positive & PIT-1 & & Acromegaly & Hyperprolactinemia \\
\hline \multicolumn{6}{|l|}{ Thyrotroph adenomas } \\
\hline TSH adenoma & TSH (PRL) & PIT-1 & & TSH-hyperfunction & Silent \\
\hline Undifferentiated TSH adenoma & TSH, PRL & PIT-1 & & TSH-hyperfunction & Hyperprolactinemia \\
\hline \multicolumn{6}{|l|}{ Plurihormonal adenomas } \\
\hline Plurihormonal PIT-1 positive adenoma & GH, PRL, TSH, others & PIT-1 & Yes & Inactive & Hyperprolactinemia \\
\hline T-PIT or SF-1 positive adenoma & Various combinations & T-PIT or SF-1 & Unclear & & \\
\hline \multicolumn{6}{|l|}{ Corticotroph adenomas } \\
\hline Densely granulated ACTH adenoma & ACTH & T-PIT & & Cushing's disease & Silent $\rightarrow$ aggressive \\
\hline Sparsely granulated ACTH adenoma & ACTH & T-PIT & & Cushing's disease & Silent $\rightarrow$ aggressive \\
\hline Crooke's cell adenoma & ACTH & T-PIT & Yes & Cushing's disease & Silent \\
\hline Gonadotroph adenomas & & & & Inactive & \\
\hline FSH or LH or FSH/LH adenoma & $\mathrm{FSH}$ and/or LH & SF-1 & & & \\
\hline a-SU adenoma & $\mathrm{a}-\mathrm{SU}$ & SF-1 & & Inactive & \\
\hline $\begin{array}{l}\text { Hormone and transcription } \\
\text { factor-negative tumors }\end{array}$ & Negative & Negative & & Inactive & \\
\hline Null-cell adenoma & Negative & Negative & & Inactive & \\
\hline
\end{tabular}

\section{Follow-up}

\section{General aspects}

\begin{tabular}{|l|l|l|}
\hline No. & Content & Consensus \\
\hline 7.1 & $\begin{array}{l}\text { Patients with evidence of a germline mutation } \\
\text { should be made aware of the possibility of a } \\
\text { genetic counseling. }\end{array}$ & Strong \\
\hline 7.2 & $\begin{array}{l}\text { After a neurosurgical intervention on the } \\
\text { pituitary gland, the patient shall be advised } \\
\text { that certain everyday and leisure activities } \\
\text { have to be avoided for a limited period of time. }\end{array}$ & Strong \\
\hline 7.3 & $\begin{array}{l}\text { Patients shall be specifically asked about } \\
\text { psychosocial consequences and concomitant } \\
\text { effects of pituitary tumors. } \\
\text { The use of questionnaires can be helpful. }\end{array}$ & Strong \\
\hline
\end{tabular}

\section{Short explanation}

A germline mutation needs to be considered especially if the patient is $\leq 30$ years old at first diagnosis of the pituitary adenoma, if other tumors are known besides the pituitary adenoma, or if there is a familial cluster of pituitary adenomas [22].

Certain activities as well as physical exercise are to be avoided after a neurosurgical intervention, at least for a certain period of time. An overview of recommendations for the postoperative course after transsphenoidal interventions that were given as examples by several German neurosurgeons is provided in > Table 5 [23]. 
- Table 5 Action recommendations after routine or extended transsphenoidal access.

\begin{tabular}{|c|c|c|c|c|c|c|}
\hline \multirow[t]{2}{*}{ Activity } & \multicolumn{3}{|c|}{$\begin{array}{l}\text { Recommended latency (weeks) after } \\
\text { routine transsphenoidal access }\end{array}$} & \multicolumn{3}{|c|}{$\begin{array}{l}\text { Recommended latency (weeks) after } \\
\text { extended transsphenoidal access }\end{array}$} \\
\hline & Variation & Median & Recommendation & Variation & Median & Recommendation \\
\hline \multicolumn{7}{|l|}{ Daily activities } \\
\hline Blow nose & $<1-8$ & 3 & $3^{\mathrm{A}}$ & $1-12$ & 4 & $4^{\mathrm{A}}$ \\
\hline Wash hair & $<1-1$ & $<1$ & $<1$ & $<1-2$ & $<1$ & $<1$ \\
\hline Sauna visit & $1-4$ & 4 & 4 & $2-12$ & 4 & 4 \\
\hline Play wind instrument & $3-12$ & 6 & $6^{\mathrm{B}}$ & $3-26$ & 8 & $6^{B}$ \\
\hline Flying & $<1-8$ & 1.5 & $1^{\mathrm{C}}$ & $<1-8$ & 2.5 & $2^{c}$ \\
\hline Heavy lifting & $<1-8$ & 4 & 4 & $1-26$ & 6 & 6 \\
\hline Drive a car & $<1-12$ & 1 & $<1^{D}$ & $<1-12$ & 4 & $2^{G}$ \\
\hline Use a CPAP device & $<1-12$ & 3.5 & $3^{\mathrm{A}}$ & $<1-12$ & 4 & $4^{\mathrm{A}}$ \\
\hline Have sexual intercourse & $<1-4$ & 1 & 1 & $<1-8$ & 3.5 & 2 \\
\hline \multicolumn{7}{|l|}{ Sports activities } \\
\hline Nordic walking & $<1-4$ & 2 & 2 & $<1-6$ & 3 & 3 \\
\hline Jogging & $<1-6$ & 4 & 3 & $<1-12$ & 5 & 4 \\
\hline Breast stroke & $1-8$ & 4 & 4 & $2-12$ & 6 & 6 \\
\hline Crawl & $1-8$ & 4 & 4 & $2-12$ & 6 & 6 \\
\hline Diving & $4-26$ & 8 & $12^{\mathrm{E}}$ & $6-\varnothing$ & 12 & $12^{\mathrm{E}}$ \\
\hline Tennis & $<1-8$ & 4 & 4 & $4-12$ & 7 & 6 \\
\hline Soccer & $<1-8$ & 4 & $4^{\mathrm{F}}$ & $4-12$ & 8 & $8^{\mathrm{F}}$ \\
\hline Competitive sports & $4-12$ & 6 & 6 & $6-12$ & 12 & 10 \\
\hline \multicolumn{7}{|c|}{ Occupational activities ( 8 hours/day) } \\
\hline Sitting activity & $<1-3$ & 1.5 & 2 & $<1-4$ & 2 & 3 \\
\hline Physical activity & $<1-6$ & 3.5 & $4^{\mathrm{A}}$ & $2-12$ & 6 & $6^{\mathrm{A}}$ \\
\hline \multicolumn{7}{|c|}{$\begin{array}{l}\text { Results were derived from a survey conducted in } 14 \text { German neurosurgeons (with a total of about } 1,000 \text { transsphenoidal operations per year). In the } \\
\text { column "Variation" the data of the neurosurgeons participating in the survey are listed with their respective range ("from...to..."). A longer after intraopera } \\
\text { tive cerebrospinal fluid flow; B starting point for gradual increase of activity; }{ }^{C} \text { exclusion of intracranial air (within the skull), e. g., by computed tomogra- } \\
\text { phy is a prerequisite; }{ }^{D} \text { provided hyponatremia is excluded and patient feels well; }{ }^{E} \text { statement of the responsible surgeon is binding; }{ }^{F} \text { no headballs; } \\
{ }^{G} \text { provided the brain surface was neither involved by the tumor nor by the surgery; } \varnothing=\text { never (for further information refer to the corresponding original } \\
\text { paper). Table modified according to [ } 23 \text { ]. Abbreviations: CPAP, continuous positive airway pressure. }\end{array}$} \\
\hline
\end{tabular}

Patients with hormone-inactive pituitary macroadenomas have been shown to suffer from an impaired quality of life as compared to age-matched healthy controls even after successful surgery or radiotherapy. A positive influence of accompanying psychosocial care (e. g. cognitive behavioral interventions) on the treatment and follow-up care of a pituitary adenoma seems to be obvious, but has not yet been verified specifically for this clinical picture ( $\vee$ Fig. 1,

$>$ Fig. 2 and $>$ Table 6 ).

\section{Immediate postoperative course (until about 2 weeks after surgery)}

After surgical resection of a pituitary adenoma, the concrete follow-up is determined mainly by the time of postoperative evaluation. The perioperative and immediate postoperative course (up to about 2 weeks after surgery) is already discussed in Chapter 5 on therapy (and there specifically in Recommendations 5.9-5.14).

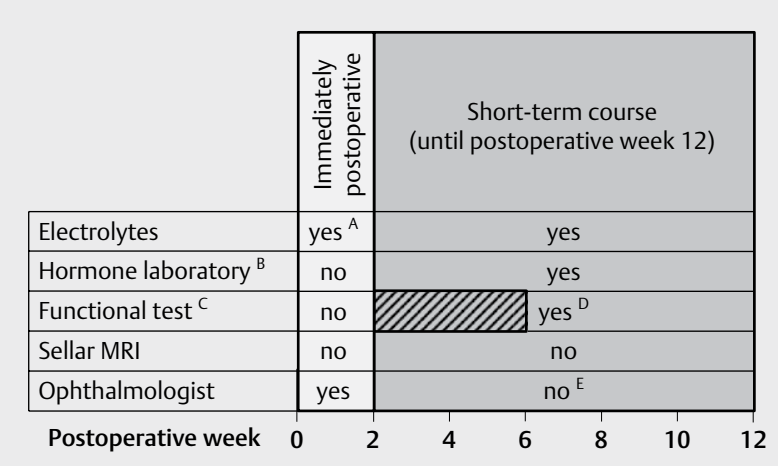

- Fig. 1 Proposal for postoperative follow-up of patients in the first 12 weeks after surgery for a hormone-inactive pituitary tumor. $\mathbf{A}$ regularly until at least the $10^{\text {th }}$ postoperative day; $\mathrm{B}$ TSH, fT4, fT3, cortisol, IGF1, LH, FSH, estradiol or total testosterone depending on sex; $\mathbf{C}$ dynamic function tests for the diagnostic workup of a possible corticotropic insufficiency (see reasoning to Recommendation 4.2); D after 6 weeks at the earliest, better after 8 , and at the latest after 12 weeks; $\mathbf{E}$ if preliminary examination is inconspicuous and if there are no clinical features, no further clinical examination is necessary in the $1^{\text {st }}$ half-year. Abbreviations: MRI, magnetic resonance imaging. 


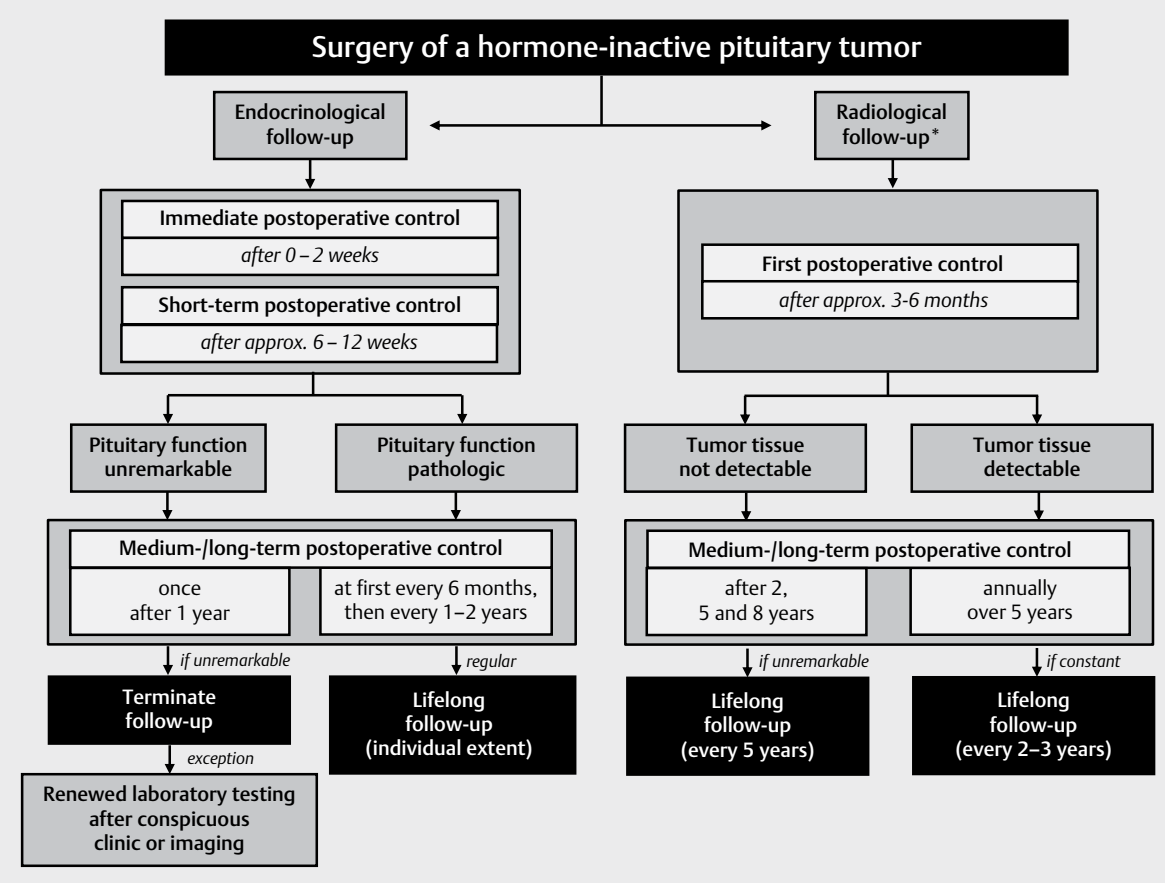

- Fig. 2 Proposal for postoperative follow-up care of patients with hormone-inactive pituitary tumors. * In principle, magnetic resonance imaging is the examination procedure of choice, in case of contraindications computed tomography may be used. Provided that there is no obvious visual impairment and imaging follow-up by magnetic resonance imaging is performed regularly, ophthalmological follow-up examinations may be omitted if there are no radiological indications of tumor contact with the visual path.

Table 6 Assessment intervals for size-stable pituitary adenomas without endocrine abnormalities.

\begin{tabular}{|c|c|c|c|c|}
\hline & \multicolumn{2}{|c|}{ First control after initial diagnosis } & \multicolumn{2}{|l|}{ Further controls } \\
\hline & Time point & Content & Time point & Content \\
\hline Microadenoma & after 12 months & $\begin{array}{l}\text { - hormonal evaluation } \\
\text { - sellar MRI }\end{array}$ & $\begin{array}{l}\text { - initially after } 24 \text { and } 36 \text { months } \\
\text { - further controls according to individual } \\
\text { - assessment (discuss length of intervals) }\end{array}$ & $\begin{array}{l}\text { - hormonal evaluation } \\
\text { - sellar MRI }\end{array}$ \\
\hline $\begin{array}{l}\text { Macroadenoma without } \\
\text { contact to structures of } \\
\text { the anterior visual tract }\end{array}$ & after 6 months & $\begin{array}{l}\text { - hormonal evaluation } \\
\text { - sellar MRI }\end{array}$ & $\begin{array}{l}\text { - annual re-evaluations over } 3 \text { years } \\
\text { (i. e., } 4 \text { controls in total, incl. initial } \\
\text { control) } \\
\text { - further controls according to individual } \\
\text { assessment (discuss length of intervals) }\end{array}$ & $\begin{array}{l}\text { - hormonal evaluation } \\
\text { - sellar MRI }\end{array}$ \\
\hline $\begin{array}{l}\text { Macroadenoma with } \\
\text { contact to structures of } \\
\text { the anterior visual tract }\end{array}$ & after 3-6 months & $\begin{array}{l}\text { - hormonal evaluation } \\
\text { - sellar MRI } \\
\text { - ophthalmologist }\end{array}$ & $\begin{array}{l}\text { - annual re-evaluations over } 3 \text { years } \\
\text { (i.e., } 4 \text { controls in total, incl. initial control) } \\
\text { - further controls according to individual } \\
\text { assessment (discuss length of intervals) }\end{array}$ & $\begin{array}{l}\text { - hormonal evaluation } \\
\text { - sellar MRI } \\
\text { - ophthalmologist }\end{array}$ \\
\hline
\end{tabular}




\section{Short-term postoperative course (until about 6-12 weeks after surgery)}

\begin{tabular}{|c|c|c|}
\hline No. & Content & Consensus \\
\hline 7.4 & $\begin{array}{l}\text { Postoperative follow-up shall be closely } \\
\text { monitored and performed according to local } \\
\text { multidisciplinary standards. } \\
\text { If local multidisciplinary standards are } \\
\text { lacking, the procedure shown in ( }>\text { Fig. } \mathbf{1} \text {, } \\
\text { > Fig. } 2 \text { and }>\text { Table 6) can be applied. }\end{array}$ & Strong \\
\hline 7.5 & $\begin{array}{l}\text { Within the first } 3 \text { months postoperatively, a } \\
\text { detailed endocrinological follow-up shall be } \\
\text { performed. } \\
\text { Endocrinological laboratory tests shall } \\
\text { include a morning-time measurement of } \\
\text { TSH, fT4, fT3, cortisol, IGF-1, LH, FSH, as well } \\
\text { as total testosterone (in men) or estradiol (in } \\
\text { premenopausal women) in all patients. } \\
\text { Secondary adrenal insufficiency shall be } \\
\text { definitively excluded after } 6 \text { weeks at the } \\
\text { earliest and } 12 \text { weeks at the latest, e. g., by } \\
\text { suitable dynamic function test (see also } \\
\text { Recommendation } 4.3 \text { ). } \\
\text { If diabetes insipidus is suspected, the urine } \\
\text { osmolality should be determined and, if } \\
\text { necessary, a corresponding functional test } \\
\text { should be performed. }\end{array}$ & Strong \\
\hline 7.6 & $\begin{array}{l}\text { In case of a proven insufficiency of the } \\
\text { corticotropic and thyrotropic axes, treatment } \\
\text { should be mandatory. } \\
\text { For other pituitary hormone insufficiencies, a } \\
\text { substitution therapy should be considered } \\
\text { (see also Recommendation } 5.9 \text {, Recom- } \\
\text { mendation } \mathbf{5 . 1 0} \text {, and Recommendation } \\
\mathbf{5 . 1 1} \text { ). Regarding an adequate training of } \\
\text { patients, see also Recommendation } 8.1 \text { and } \\
\text { Recommendation } \mathbf{8 . 2} \text {. }\end{array}$ & Strong \\
\hline 7.7 & $\begin{array}{l}\text { Provided that there is no obvious impairment } \\
\text { and radiological follow-up by magnetic } \\
\text { resonance imaging is performed regularly, } \\
\text { ophthalmological follow-up examinations } \\
\text { can be dispensed with if there is no } \\
\text { radiological evidence of tumor contact with } \\
\text { the visual path. }\end{array}$ & Strong \\
\hline
\end{tabular}

\section{Short explanation}

In the case of hormone deficiency conditions that are already known preoperatively or have newly arisen in the course of the underlying disease, it is advisable to initiate appropriate diagnostics shortly after surgery in order to be able to adequately adapt or start a necessary substitution therapy. In the full version of this guideline (see Appendix) detailed considerations on diagnostic and therapeutic management of pituitary insufficiency are provided. Suggestions for postoperative diagnostics are summarized in > Fig. 1 .

\section{Medium and long-term postoperative course}

Regular follow-up examinations are necessary also in the long-term course. The individual control interval depends, e. g., on preoperative findings (i. e., tumor size, presence and extent of hormonal impairment), the surgical outcome (i. e., complete or partial resection), and the postoperative course.

\begin{tabular}{|c|c|c|}
\hline No. & Content & Consensus \\
\hline 7.8 & $\begin{array}{l}\text { If postoperative pituitary function is sufficient, } \\
\text { detailed biochemical diagnostics should be } \\
\text { performed } 1 \text { year after surgery. } \\
\text { If the results are again inconspicuous, further } \\
\text { endocrine follow-up care should be termi- } \\
\text { nated. } \\
\text { If pituitary insufficiency becomes apparent, } \\
\text { endocrine follow-up care should be carried out } \\
\text { initially every } 6 \text { months and later on every } 1-2 \\
\text { years for the rest of the patient's life. }\end{array}$ & Strong \\
\hline 7.9 & $\begin{array}{l}\text { A first MRI control should be performed 3-6 } \\
\text { months postoperatively. } \\
\text { If no residual or recurrent tumor is detected, } \\
\text { the next MRI control should be performed } 2 \\
\text { years after surgery. } \\
\text { If the course is inconspicuous, the neuroradio- } \\
\text { logical control intervals should then be further } \\
\text { extended (to every } 3 \text { years, thus, re-imaging is } \\
\text { done } 5 \text { and } 8 \text { years after the operation). } \\
\text { If there is still no evidence of recurrence after } 8 \\
\text { years of follow-up imaging, long-term } \\
\text { follow-up imaging should only be performed } \\
\text { every } 5 \text { years. } \\
\text { If a residual tumor is detected in the first } \\
\text { postoperative MRI control, further imaging } \\
\text { should initially be performed annually for } 5 \\
\text { years. } \\
\text { If the results are stable, the control interval can } \\
\text { then be extended (e. g., to every } 2-3 \text { years). } \\
\text { In all cases, lifelong radiological follow-up care } \\
\text { should be offered. }\end{array}$ & Strong \\
\hline 7.10 & $\begin{array}{l}\text { If a tumor recurrence or a relevant growth of } \\
\text { postoperatively remaining tumor tissue is } \\
\text { suspected, concrete recommendations for } \\
\text { further procedures shall be determined (if } \\
\text { possible, in a multidisciplinary case conference } \\
\text { with endocrinological, neurosurgical, (neuro-) } \\
\text { pathological, (neuro-) radiological, ophthalmo- } \\
\text { logical, and radiotherapeutical participation). }\end{array}$ & Strong \\
\hline 7.11 & $\begin{array}{l}\text { In case of stable long-term impairment of the } \\
\text { visual function as well as missing residual/ } \\
\text { recurrent tumor, the necessity of regular } \\
\text { ophthalmological follow-up should be } \\
\text { evaluated. } \\
\text { If new ophthalmological deficits occur or a } \\
\text { possible tumor contact to the visual pathway is } \\
\text { present (e. g., suspicious findings in a control } \\
\text { MRI), an ophthalmological examination shall be } \\
\text { arranged promptly. } \\
\text { Depending on the long-term course of the } \\
\text { disease, shorter or longer control intervals } \\
\text { should also be considered, if appropriate. }\end{array}$ & Strong \\
\hline
\end{tabular}

\section{Short explanation}

Concrete recommendations regarding the ideal intervals of imaging controls are difficult to give due to the very limited data available so far. $>$ Fig. 2 provides an orientation.

According to current data, recurrence is observed in $10-33 \%$ of cases after pituitary surgery alone, whereby the risk is significantly lower if no residual tumor tissue is detectable in the postoperative MRI. 
The contents of long-term ophthalmological follow-up care basically correspond to the recommendations for ophthalmological diagnostics in the short-term postoperative course, and are therefore not discussed here in detail.

\section{Follow-up care after radiotherapeutic interventions}

\begin{tabular}{|l|l|l|}
\hline No. & Content & Consensus \\
\hline 7.12 & $\begin{array}{l}\text { After radiotherapy, regular radiotherapeu- } \\
\text { tic follow-up involving magnetic } \\
\text { resonance imaging shall be performed. }\end{array}$ & Strong \\
\hline 7.13 & $\begin{array}{l}\text { After radiotherapy of hormone-inactive } \\
\text { pituitary tumors, endocrine follow-up } \\
\text { should be performed throughout the } \\
\text { patient's life. } \\
\text { The intervals of the ophthalmological } \\
\text { follow-up should be determined } \\
\text { individually. }\end{array}$ & Strong \\
\hline
\end{tabular}

\section{Short explanation}

For Germany, the obligation for permanent radiotherapeutic aftercare by a competent and expert physician results from German law and regulations (e. g., the Radiation Protection Act and the current guideline "Radiation Protection in Medicine") and serves for quality assurance of the radiation application. Therefore, after radiotherapy, a life-long clinical radiotherapeutic follow-up care has to be performed.

Pituitary axis insufficiencies usually occur with a considerable latency to radiotherapy, the majority after 2-4 years; however, up to $30 \%$ of post-therapeutic insufficiencies manifest significantly later than 5 years after radiotherapy. Long-term endocrine controls are, therefore, necessary. These are initially to be carried out every 6-12 months and may be extended over time, depending on the findings.

Likewise, radiogenic damage to the optical system may occur with a significant delay, although the overall incidence is very low.

\section{Follow-up care of patients without previous pituitary surgery}

Regarding the sole follow-up of non-functional pituitary adenomas only few prospective data are available, and many recommendations are therefore expert opinions. Guidance is provided by the published recommendations of the Endocrine Society [6]. Suggestions for assessment intervals for size-stable pituitary adenomas without endocrine abnormalities are given in > Table 6 .

\begin{tabular}{|c|c|c|}
\hline No. & Content & Consensus \\
\hline 7.14 & $\begin{array}{l}\text { For microadenomas, endocrine follow-up } \\
\text { shall initially be performed after approx. } \\
12 \text { months and then once a year for } 3 \text { years. } \\
\text { In case of consistently inconspicuous } \\
\text { findings, subsequent examination intervals } \\
\text { are determined individually. } \\
\text { For macroadenomas, endocrinological } \\
\text { follow-up shall initially be performed after } \\
3-6 \text { months and then once a year for } 3 \\
\text { years. In case of consistently inconspicuous } \\
\text { findings, subsequent examination intervals } \\
\text { are determined individually. }\end{array}$ & Strong \\
\hline 7.15 & $\begin{array}{l}\text { For microadenomas, radiological follow-up } \\
\text { by MRI of the sellar region shall initially be } \\
\text { carried out once a year for } 3 \text { years. In case of } \\
\text { consistently inconspicuous findings, } \\
\text { subsequent examination intervals are } \\
\text { determined individually. }\end{array}$ & Consensus \\
\hline 7.16 & $\begin{array}{l}\text { For macroadenomas without contact to } \\
\text { structures of the anterior visual path, } \\
\text { radiological follow-up by MRI of the sellar } \\
\text { region shall initially be carried out after } \\
\text { about } 6 \text { months and then once a year for } 3 \\
\text { years. In case of consistently inconspicuous } \\
\text { findings, subsequent examination intervals } \\
\text { are determined individually. } \\
\text { For macroadenomas with contact to } \\
\text { structures of the anterior visual path, a } \\
\text { radiological follow-up by MRI of the sellar } \\
\text { region shall initially be carried out after } \\
\text { about 3-6 months and then once a year for } \\
3 \text { years. In case of constantly inconspicuous } \\
\text { findings, further examination intervals are } \\
\text { individually determined. }\end{array}$ & Strong \\
\hline 7.17 & $\begin{array}{l}\text { In case of radiological detection of pituitary } \\
\text { tumors with contact to or compressing the } \\
\text { optic tract, a visual field examination and, } \\
\text { optionally, an optical coherence tomography } \\
\text { (OCT) shall be performed as an obligatory } \\
\text { procedure. In patients with a pituitary lesion } \\
\text { that does not reach the structures of the } \\
\text { visual system and who regularly receive } \\
\text { follow-up care by MRI imaging, an } \\
\text { ophthalmological examination can be } \\
\text { dispensed with. }\end{array}$ & Strong \\
\hline
\end{tabular}

\section{Short explanation}

Frequently, pituitary microadenomas are not accompanied by any relevant clinical or biochemical alterations. In contrast, a clinically relevant restriction of pituitary function was described in macroadenomas (including the gonadotropic axis in about one in three women and up to $40 \%$ of men). Data regarding the ideal imaging intervals for pituitary adenomas are limited. Upon initial detection of a macroadenoma, sellar imaging is to be induced in the long term, as tumor growth within 4-5 years occurs in up to $50 \%$ of cases. In addition, pituitary apoplexy within 5 years is observed in about $10 \%$ of cases [24].

Some authors recommend neither radiological nor endocrine long-term follow-up in the case of incidental microadenomas $<5 \mathrm{~mm}$ [16]. Some members of the guideline committee are 
of the opinion that in the subgroup of very small, clinically inactive microadenomas, follow-up is not absolutely necessary and, if the findings are stable in size, no further imaging is required after 12 months.

In the case of asymptomatic hormone-inactive macroadenomas, refraining from lifelong MRI controls needs to be discussed if size constancy is documented over a longer period of time. There is no evidence for or against imaging controls in the available literature. However, in case of impairment of the anterior optic tract, we recommend to continue the imaging control.

\section{Consulting and Training of Patients}

\begin{tabular}{|l|l|l|}
\hline No. & Content & Consensus \\
\hline 8.1 & $\begin{array}{l}\text { Patients with non-functioning pituitary } \\
\text { tumors (and also, if possible, their reference } \\
\text { persons) shall be counseled regarding the } \\
\text { characteristics by which a deficiency of vital } \\
\text { hormones (e. g., cortisol, thyroid hormones, } \\
\text { and ADH) and/or a syndrome of inadequate } \\
\text { antidiuresis can be recognized and how they } \\
\text { are treated. }\end{array}$ & Strong \\
\hline 8.2 & $\begin{array}{l}\text { If secondary adrenal insufficiency is } \\
\text { suspected or has already been diagnosed, } \\
\text { patients shall receive an emergency card and } \\
\text { an emergency kit. } \\
\text { In addition, these patients should be trained } \\
\text { (ideally together with a reference person) } \\
\text { using structured training and treatment } \\
\text { programs (with regular repetition throughout } \\
\text { the course of the disease) }\end{array}$ & \\
\hline 8.3 & $\begin{array}{l}\text { Patients with non-functioning pituitary } \\
\text { adenomas shall be provided with relevant } \\
\text { medical documents (e. g., discharge letter, } \\
\text { investigational reports). } \\
\text { Patients (and also, if possible, their reference } \\
\text { persons) shall be informed by the responsible } \\
\text { medical staff that further treatment in a } \\
\text { center or practice specialized in pituitary } \\
\text { diseases is advisable. }\end{array}$ & \\
\hline 8.4 & $\begin{array}{l}\text { Patients with non-functioning pituitary } \\
\text { tumors (and also, if possible, their reference } \\
\text { persons) shall be made aware of disease- } \\
\text { related patient organizations (including } \\
\text { self-help groups) by the responsible medical } \\
\text { staff (e. g., physicians, endocrinology } \\
\text { assistants). }\end{array}$ & Strong \\
\hline
\end{tabular}

\section{Short explanation}

Rare diseases are frequently recognized late or misinterpreted. It is therefore essential that all patients with pituitary macrotumors or former surgery or radiation of the sellar region (and their reference persons) are sufficiently informed about possible symptoms of pituitary insufficiency so that they consult an endocrinologist for diagnosis at an early stage if needed. As especially the failure of the corticotropic and thyrotropic axis is frequently able to lead to (lifethreatening) complaints, education on these two conditions is most necessary. An emergency card allows for rapid identification of affected patients by healthcare professionals. In addition, in the first days and weeks after a surgical intervention in the sellar re- gion, affections of the posterior pituitary lobe (including disturbances of the water balance) may occur.

Parallel to this guideline, a separate patient brochure has been produced, which addresses the specific aspects of the guideline and in particular patient education.

In general, it appears very reasonable that patients receive all relevant medical documents concerning their own medical history.

Support in self-management by a self-help group is a great relief for many patients.

\section{Special Patient Groups}

\section{Patients with involuntary childlessness}

\begin{tabular}{|l|l|l|}
\hline No. & Content & Consensus \\
\hline 9.1 & $\begin{array}{l}\text { In case of an involuntary childlessness } \\
\text { associated with a clinically non-functioning } \\
\text { pituitary tumor and consecutive hypogon- } \\
\text { adotropic hypogonadism, involvement of a } \\
\text { fertility center should be offered. }\end{array}$ & Strong \\
\hline 9.2 & $\begin{array}{l}\text { Prior to a planned pregnancy, surgical } \\
\text { resection should be discussed in the case of } \\
\text { tumors (especially if they are larger than } \\
1 \text { cm) that could potentially impair visual } \\
\text { function during the course of the } \\
\text { pregnancy. } \\
\text { Patients who do not undergo pituitary } \\
\text { surgery shall have regular ophthalmological } \\
\text { examinations during pregnancy (at least } \\
\text { every 3 months). }\end{array}$ & \\
\hline
\end{tabular}

\section{Short explanation}

Hormone-inactive pituitary adenomas may cause cycle disturbances/amenorrhea, reduced libido and fertility and, consequently, involuntary childlessness. However, appropriate hormonal stimulation therapy is usually able to restore fertility.

Prior to a planned pregnancy it is advantageous to surgically resect hormone-inactive pituitary macroadenomas or large microadenomas, since tumors may grow during pregnancy. This applies especially to tumors that are located in relative proximity to the visual pathway. Without surgery, at least regular ophthalmological and, if necessary, radiological controls are to be arranged in order to detect a potential threat to the visual pathway as early as possible. 


\section{Pregnant patients}

\begin{tabular}{|c|c|c|}
\hline 9.3 & $\begin{array}{l}\text { If there is a clinical need for imaging of the sellar } \\
\text { region during pregnancy, this should be done by } \\
\text { means of native magnetic resonance imaging. } \\
\text { A contrast medium should only be administered in } \\
\text { justified exceptional cases. }\end{array}$ & Strong \\
\hline 9.4 & $\begin{array}{l}\text { If surgery in the sellar region becomes necessary } \\
\text { during pregnancy, it should be performed in the } \\
2^{\text {nd }} \text { trimester, if possible. }\end{array}$ & Strong \\
\hline 9.5 & $\begin{array}{l}\text { During pregnancy, hormone parameters are often } \\
\text { difficult to interpret. Before any hormonal } \\
\text { evaluation of pregnant women, it shall therefore } \\
\text { be determined whether the planned diagnostic test } \\
\text { has any meaningful therapeutic consequences. }\end{array}$ & Strong \\
\hline 9.6 & $\begin{array}{l}\text { If a hormone-inactive pituitary tumor is present } \\
\text { during pregnancy, thyroid gland levels shall be } \\
\text { measured once per trimester, irrespective of any } \\
\text { pre-existing thyroid pathologies. } \\
\text { In case of pre-existing hypothyroidism, an } \\
\text { immediate escalation of the levothyroxine dose is } \\
\text { regularly required after confirmation of pregnancy, } \\
\text { thereby addressing the increased thyroid hormone } \\
\text { requirement and ensuring sufficient child } \\
\text { development. If hypothyroidism is highly suspected } \\
\text { and the laboratory findings are inconclusive, further } \\
\text { diagnostics shall be applied (including determina- } \\
\text { tion of thyroid autoantibodies and thyroid } \\
\text { ultrasound), followed by the initiation or adaptation } \\
\text { of a substitution therapy with levothyroxine, if } \\
\text { necessary. }\end{array}$ & Strong \\
\hline 9.7 & $\begin{array}{l}\text { While the substitution dose of hydrocortisone in } \\
\text { case of known adrenal insufficiency usually does } \\
\text { not need to be adjusted during pregnancy (at least } \\
\text { in the first and second trimester), the dose shall be } \\
\text { adequately increased during the birth process. }\end{array}$ & Strong \\
\hline
\end{tabular}

\section{Short explanation}

Diagnosis and therapy of pituitary adenomas in pregnancy are challenging. Typical physiological changes may complicate or delay the recognition of the underlying disease, while therapeutic options are limited.

The determination of prolactin and alpha-subunit in the context of pregnancy is generally not useful due to the physiologically elevated values in this scenario.

Contrast medium is usually not administered, since severe pathologies are often detectable without contrast medium and contrast medium-induced fetal damage may occur.

Since the volume of the pituitary increases during pregnancy (due to hyperplasia of the prolactin-producing cells), a relevant space requirement may develop. Consecutive symptoms may be (partial) pituitary dysfunctions and/or a chiasmal syndrome.

In the case of severe visual disturbances or the occurrence of a pituitary apoplexy surgical intervention may be necessary. The $2^{\text {nd }}$ trimester is the most appropriate time for surgery, as fetal organogenesis has already been completed and compression of the vena cava during the procedure is not yet a probable complication (other than in advanced pregnancy).

If secondary hypothyroidism is suspected or already known, only fT4 is used to assess thyroid function or to determine the required substitution dose. The American guidelines recommend to measure total T4 that appears to be particularly useful if the fT4 values are implausible. However, total T4 is nowadays rarely available in Germany.

Patients with known adrenal insufficiency usually do not require an adjustment of the hydrocortisone substitution dose if the course of the pregnancy is uncomplicated; a slight dose escalation might be necessary in the $3^{\text {rd }}$ trimester [25-27]. In the context of childbirth, however, an adequate dose escalation is essential.

\section{Patients with relevant morbidity or frailty}

\begin{tabular}{|l|l|l|}
\hline 9.8 & $\begin{array}{l}\text { Before any diagnostics in frail and multimorbid } \\
\text { patients, it shall always be considered whether } \\
\text { possible therapeutic consequences can be drawn. } \\
\text { Before any surgery, a risk assessment shall be } \\
\text { carried out. }\end{array}$ & Strong \\
\hline 9.9 & $\begin{array}{l}\text { Especially in (severely) obese patients the } \\
\text { increased risk of cerebrospinal fluid fistulas } \\
\text { should be considered postoperatively. }\end{array}$ & Strong \\
\hline 9.10 & $\begin{array}{l}\text { Patients with hormone-inactive pituitary tumors } \\
\text { under therapy with platelet aggregation } \\
\text { inhibitors or oral anticoagulants are at an } \\
\text { increased risk of bleeding and require a special } \\
\text { risk assessment and preparation before any } \\
\text { surgical intervention. An early multidisciplinary } \\
\text { exchange regarding the therapeutic procedure } \\
\text { should always be aimed at. }\end{array}$ & Strong \\
\hline
\end{tabular}

\section{Short explanation}

To estimate the overall risk of general anesthesia, various scores have been used. One of the best known was proposed by the American Society of Anesthesiologists (ASA) [28]. By division of the physical condition into six groups, the so-called ASA classification allows a simplified risk assessment.

A special feature is the increased risk of cerebrospinal fluid fistulas in obese patients, which increases with higher body mass index.

For patients taking oral anticoagulants, general rules for surgical procedures apply. Multidisciplinary consultation and determination of the perioperative anticoagulation regimen is always to be sought. Preoperative discontinuation of oral anticoagulants and postoperative prophylaxis with low-molecular-weight heparins are generally appropriate. These recommendations are not specific to the perioperative management of patients with pituitary adenomas, but are derived from other (neuro-) surgical operations [29].

\section{Funding}

The guideline was initiated by the German Society of Endocrinology. All incurring costs were financed exclusively by the German Society of Endocrinology and the participating professional societies. 


\section{Acknowledgement}

We are thankful to Cornelia Schmutzler for translating the original guideline manuscript and to Cathleen Muche-Borowski and Katharina Spek for their assistance in the development process of the guideline documents. We are also grateful for the commitment and constructive collaboration of the participating societies and groups.

\section{Conflict of interest}

The authors declare that there is no conflict of interest that could be perceived as prejudicing the impartiality of the research reported. A detailed list of all reported potential conflicts of interests is given at https://www.awmf.org/fileadmin/user_upload/Leitlinien/089_D_Ges_ fuer_Endokrinologie/089-002i_S2k_Diagnostik-Therapie-hormonaktiver-Hypophsenaddenome_2020-02.pdf

\section{References}

[1] Alexander EK, Pearce EN, Brent GA et al. Guidelines of the American Thyroid Association for the Diagnosis and Management of Thyroid Disease During Pregnancy and the Postpartum. 2017; Thyroid 27: 315-389

[2] American College of O, Gynecologists' Committee on Obstetric P Committee OpinionSummary: Guidelines for Diagnostic Imaging During Pregnancy and Lactation. Obstet Gynecol 2016; 127: 418

[3] Casanueva FF, Molitch ME, Schlechte JA et al. Guidelines of the Pituitary Society for the diagnosis and management of prolactinomas. Clin Endocrinol (Oxf) 2006; 65: 265-273

[4] De Groot L, Abalovich M, Alexander EK et al. Management of thyroid dysfunction during pregnancy and postpartum: an Endocrine Society clinical practice guideline. J Clin Endocrinol Metab 2012; 97: 2543-2565

[5] Fleseriu M, Bodach ME, Tumialan LM et al. Congress of neurological surgeons systematic review and evidence-based guideline for pretreatment endocrine evaluation of patients with nonfunctioning pituitary adenomas. Neurosurgery 2016; 79: E527-E529

[6] Freda PU, Beckers AM, Katznelson L et al. Pituitary incidentaloma: An endocrine society clinical practice guideline. J Clin Endocrinol Metab 2011; 96: 894-904

[7] Inder W], Hunt P]. Glucocorticoid replacement in pituitary surgery: Guidelines for perioperative assessment and management. J Clin Endocrinol Metab 2002; 87: 2745-2750

[8] Katznelson L, Laws ER Jr., Melmed S et al. Acromegaly: An endocrine society clinical practice guideline. J Clin Endocrinol Metab 2014; 99: 3933-3951

[9] Kuo JS, Barkhoudarian G, Farrell C] et al. Congress of neurological surgeons systematic review and evidence-based guideline on surgical techniques and technologies for the management of patients with nonfunctioning pituitary adenomas. Neurosurgery 2016; 79 : E536-E538

[10] Lucas JW, Bodach ME, Tumialan LM et al. Congress of neurological surgeons systematic review and evidence-based guideline on primary management of patients with nonfunctioning pituitary adenomas. Neurosurgery 2016; 79: E533-E535
[11] Melmed S, Casanueva FF, Hoffman AR et al. Diagnosis and treatment of hyperprolactinemia: An Endocrine Society clinical practice guideline. J Clin Endocrinol Metab 2011; 96: 273-288

[12] Nieman LK, Biller BM, Findling JW et al. The diagnosis of Cushing's syndrome: An Endocrine Society Clinical Practice Guideline. J Clin Endocrinol Metab 2008; 93: 1526-1540

[13] Raverot G, Burman P, McCormack A et al. European Society of Endocrinology Clinical Practice Guidelines for the management of aggressive pituitary tumours and carcinomas. Eur J Endocrinol 2018; 178: G1-G24

[14] Nomikos P, Ladar C, Fahlbusch R et al. Impact of primary surgery on pituitary function in patients with non-functioning pituitary adenomas -- a study on 721 patients. Acta Neurochir (Wien) 2004; 146: 27-35

[15] Raverot G, Assie G, Cotton F et al. 2015; Biological and radiological exploration and management of non-functioning pituitary adenoma. Ann Endocrinol (Paris) 76: 201-209

[16] Chanson P, Raverot G, Castinetti F et al. French Endocrinology Society non-functioning pituitary adenoma w-g 2015 Management of clinically non-functioning pituitary adenoma. Ann Endocrinol (Paris). 76: $239-247$

[17] Puataweepong P, Dhanachai M, Hansasuta A et al. Clinical outcomes of perioptic tumors treated with hypofractionated stereotactic radiotherapy using CyberKnife(R) stereotactic radiosurgery. J Neurooncol 2018; 139: 679-688

[18] Louis DN, Perry A, Reifenberger G et al. The 2016 World Health Organization Classification of Tumors of the Central Nervous System: A summary. Acta Neuropathol 2016; 131: 803-820

[19] Osamura R, Lopes MBS, Grossman A et al. Tumours of the pituitary gland. In: Lloyd RV, Osamura RY, Klöppel G, Rosai J, (Eds). WHO Classification of Tumours of Endocrine Organs. 4 ed.Heidelberg-Berlin: Springer; 2017

[20] Ronchi CL, Peverelli E, Herterich S et al. Landscape of somatic mutations in sporadic $\mathrm{GH}$-secreting pituitary adenomas. Eur J Endocrinol 2016; 174: 363-372

[21] Sbiera S, Perez-Rivas LG, Taranets L et al. Driver mutations in USP8 wild type Cushing's disease. Neuro Oncol. 2019;

[22] lacovazzo D, Hernandez-Ramirez LC, Korbonits M. Sporadic pituitary adenomas: the role of germline mutations and recommendations for genetic screening. Expert Rev Endocrinol Metab 2017; 12: 143-153

[23] Knappe U], Moskopp D, Gerlach R et al. Consensus on Postoperative Recommendations After Transsphenoidal Surgery. Exp Clin Endocrinol Diabetes 2019; 127: 29-36

[24] Arita K, Tominaga A, Sugiyama K et al. Natural course of incidentally found nonfunctioning pituitary adenoma, with special reference to pituitary apoplexy during follow-up examination. J Neurosurg 2006; 104: 884-891

[25] Irvine W], Barnes EW. Adrenocortical insufficiency. Clinics in Endocrinology and Metabolism 1972; 1: 549-594

[26] Knowlton Al, Baer L. Cardiac failure in Addison's disease. Am J Med 1983; 74: 829-836

[27] Lindsay JR, Nieman LK. The hypothalamic-pituitary-adrenal axis in pregnancy: Challenges in disease detection and treatment. Endocr Rev 2005; 26: 775-799

[28] Saklad M. Grading of patients for surgical procedures. Anesthesiology 1941; 2: 281-284

[29] Gerlach R, Krause M, Seifert V et al. Hemostatic and hemorrhagic problems in neurosurgical patients. Acta Neurochir (Wien) 2009; 151: 873-900. Discussion 900 